\title{
Variables That Differentiate College Students with High and Low Level of Dating Violence: An Analysis by Gender
}

\author{
Teresa Iveth Sotelo Quiñonez ${ }^{1}$, Raquel García Flores ${ }^{1}$, Angel Alberto Valdés Cuervo ${ }^{2}$, Jesús Tánori Quintana ${ }^{2} \&$ \\ Teodoro Rafael Wendlandt Amezaga ${ }^{3}$ \\ ${ }^{1}$ Department of Psychology, Instituto Tecnológico de Sonora, Ciudad Obregón, Sonora, Mexico \\ ${ }^{2}$ Department of Education, Instituto Tecnológico de Sonora, Ciudad Obregón, Sonora, Mexico \\ ${ }^{3}$ Department of Management, Instituto Tecnológico de Sonora, Ciudad Obregón, Sonora, Mexico \\ Correspondence: Teresa Iveth Sotelo Quiñonez, Instituto Tecnológico de Sonora, Calle 5 de Febrero, No. 818 \\ Sur, C.P. 85000, Ciudad Obregón, Sonora, México. E-mail: teresa.sotelo@itson.edu.mx
}

Received: March 15, 2016

doi:10.5539/ijps.v8n2p86

\author{
Accepted: April 2, 2016 \\ Online Published: April 15, 2016 \\ URL: http://dx.doi.org/10.5539/ijps.v8n2p86
}

\begin{abstract}
An inquiry was made with respect to differences in personal variables (gender stereotypes, depression, and substance abuse) and relational (tensions in the couple's relationship and support) in college students with high and low level of violence in dating. A non-random sample of 769 students was selected from a university in southern Sonora of which 397 (52\%) were included in the group with high and 372 (48\%) with a low level of violence respectively. By discriminant analysis was found that in both genders groups with low level of dating violence reported greater support and lower tensions in the couple's relationship, also men with lesser violence reported lower substance use and hostile sexism. From the results it can be concluded that dating violence is associated in women with relational variables and in the case of men to a combination of relational and personal aspects.
\end{abstract}

Keywords: dating violence, university students, gender, sexism

\section{Introduction}

Dating is an emotional relationship between two persons who feel emotional and physical attraction and seek to share their experiences (Castro \& Casique, 2010). This is a common type of relationship between young people in which there are different degrees of commitment and openness to sexual privacy of those involved (Castro \& Casique, 2010; Vargas, 2012). In most cases dating favors personal and emotional development of young people (Ellis, Chung-Hall, \& Dumas, 2013; Morales \& Díaz, 2013), however this relationship negatively affects those implicated when violence it is present among them (Ramírez-Rivera \& Núñez, 2010; Rojas-Solís, 2011; Rojas-Solís \& Carpenter, 2011; Saldivia \& Vizcarra, 2012; Vázquez \& Castro, 2008). The dating violence is defined as "any act, omission, attitude or expression that produces or has the potential to generate emotional, physical or sexual harm to the affective partner with whom an intimate relationship without cohabitation or marriage bond is shared" (Castro \& Casique, 2010, p. 22).

Violence in dating are associated with depression, anger control (Clarey, Hokoda, \& Ulloa, 2010), poor school performance (Rivera-Rivera, Allen, Rodríguez-Ortega, Chávez-Ayala, \& Lazcano-Ponce, 2006; Vázquez, Torres, Otero, White, \& López, 2010), substance abuse, risky sexual behaviors, unintended pregnancies and suicidal tendencies (Silverman, Raj, Mucci, \& Hathaway, 2001). Since in youth it is where the interaction patterns are formed in the relationships (Pepler, 2012; Wekerle \& Wolfe, 1999) the violence that occurs in this stage lingers in many cases in the relationships established in adult life (Fritz, Slep, \& O'Leary, 2012; González-Ortega, Echeburúa, \& Corral, 2008; Vizcarra \& Póo, 2010; Tharp, 2012).

In Mexico investigations show that dating violence is a problem that affects a large group of young people. In the state of Morelos it was found that $28 \%$ of women in the sample reported violence in their romantic relationships (Rivera-Rivera et al., 2006). In a study conducted in Monterrey it was found that $83 \%$ of women had been victims of psychological dating violence and $77.4 \%$ acted as the aggressor (Guzmán, Esparza, Alcántara, Escobedo, \& Henggeler, 2009). In the state of Mexico it was found that $34 \%$ of university women students reported psychological violence accompanied by other types of violence (physical, economic and sexual), $31 \%$ 
indicated to suffer from three types of violence, $12 \%$ mentioned to have the four types, and only $2 \%$ allude to not perceive violence in their relationship (Olvera, Arias, \& Amador, 2012). Finally, it should be noted that the National Survey of Violence in dating relationships ([ENVINOV for its anacronym in Spanish], 2007) reported that $76 \%$ of young people between 15 and 24 years stated having been the victims of dating violence, being physical $(6.79 \%)$, emotional $(39.38 \%)$ and sexual $(8.16 \%)$ the most frequent types.

The dating violence is a problem that must be addressed from a multidimensional perspective because it is the result of the interaction of variables located in the individual, couple, the family and the social and cultural contexts in which the relationship develops (López, Moral, Díaz-Loving, \& Cienfuegos, 2013). Taking this in consideration, the present study investigates individual factors (depression, substance abuse and gender stereotypes) and relational (support and tensions in the couple) associated with violence in dating relationships in young university students.

Among the personal factors associated with violence in dating the presence of depression is mentioned by one or both members of the couple (Rivera-Rivera et al., 2006), substance abuse (Guzmán, Esparza, Alcántara, Escobedo, \& Henggeler, 2012; McNaughton, Foshee, Bauer, \& Ennett, 2012; Rothman, McNaughton, Johnson, \& LaValley, 2012; Temple, Shorey, Fite, Stuart, \& Donna, 2013) and gender stereotypes that involved beliefs about the supremacy of man (Vázquez \& Castro, 2008), defined as hostile sexism and/or the perception of women as fragile and in need of care, called benevolent sexism (Cruz, Zempoalteclat, \& Correa, 2005; Rojas-Solís \& Carpenter, 2011).

Violence in dating are also related to dyadic processes occurring in the couple as tensions or conflicts, often associated with differences in expectations of each member regarding closeness, loyalty, intimacy, control and commitment (Draucker, Martsolf, \& Stephenson, 2012). Another dyadic factor correlated with dating violence is the perception of support in the relationship (Castro \& Casique, 2010; López et al., 2013).

This study contributes to the understanding of the factors associated with violence in young Mexicans by investigating the differences associated with personal variables (depression, substance use, gender stereotypes) and relational (tensions in the couple's relationship and support) in college students with low and high frequency of dating violence. A separate analysis was performed by sex, considering that in the literature is reported that the experience of dating violence and the factors associated with it are different in men and women (Foshee, 1996; Gover, Jennings, \& Tewksbury, 2009).

\section{Method}

\subsection{Participants}

In a not probabilistically manner were selected 769 students in the first semester of degree at a public university in southern Sonora. Of these, 244 (31.7\%) belong to the Department of Social Sciences and Humanities, 133 (17.3\%) of Economics and Management Sciences, 332 (43.2\%) of Engineering and Technology, and 60 (7.8\%) of Natural Resources. Of the total, of 358 students (46.6\%) were women and $411(53.4 \%)$ men, ranged in age range of 17-26 years.

The sample was divided into two groups according to the frequency of reports of dating violence. The first group was composed of 397 (52\%) students with low level of dating violence (obtaining a score $<50$ on the scale of dating violence). The second was integrated of $372(48 \%)$ students who reported high level of violence in this relationship (with a score $\geq 50$ on the dating violence scale).

\subsection{Instruments}

Dating violence. We used the measument instrument designed by the Mexican Youth Institute and the National Institute of Statistics and Geography ([INEGI, for its acronym in Spanish], 2007) that measures the presence of physical dating violence (16 items, e.g., Hair pulling, $\alpha=.90)$ and psychological (13 items, e.g., threaten to hurt himself if the relationship ends, $\alpha=.78)$. It was answered by a Likert-type scale with three optional responses ( 0 [Never], 1 [Sometimes], and 2 [Always]).

Tensions in the couple's relationship. It was developed by INEGI (2007) to measure the presence of strains of the pair ([14 items] e.g., Be agreed on something and not fulfill it). It was answered by a Likert-type scale with three response options ( 0 [Never], 1 [Sometimes], and 2 [Always]). Its reliability measured with Cronbach's alpha was .65.

Partner support. This instrument developed by INEGI (2007) measured the experienced support by the couple in courtship ([13 items] e.g., Your partner is a support for you in everything you do). It was answered with a 
Likert-type scale with three optional responses (0 [Never], 1 [Sometimes], and $2[$ Always] $)$. Its reliability measured with Cronbach's alpha was .73.

Sexism. This scale was developed by Recio, Square and Ramos (2007) to evaluate beliefs that are attributed to people for being male or female by 26 items. To strengthen the metric properties of the scale an exploratory factor analysis with maximum likelihood rotation method Oblimin was performed from which a solution of 18 items grouped into two factors that together explained that $48.5 \%$ of the variance of the scores.

As in the original proposal two factors were identified: hostile sexism (12 items, $\alpha=.92)$, which measures beliefs involving male superiority (e.g., You have to put women in their place so they do not dominate the man) and benevolent sexism ( 6 items, $\alpha=.78$ ), which are related to the fragility of women and therefore the intention of the men take care (e.g., Affection and love are more important for women than for men). The instrument was answered by a Likert-type scale with six optional responses (1 [Strongly disagree], 2 [Rather disagree], 3 [Somewhat disagree], 4 [Somewhat agree], 5 [Good agreement] and 6 [Totally agree]).

Depression. An adaptation of Beck's Depression Inventory (BDI) was made to be used for Mexican population by Jurado et al. (1998). This version consists of 21 items (e.g., I feel sad all the time) and was responded with a Guttman scale with four response options ranging from low to high intensity (0 [I do not feel sad], 1 [I feel sad], 2 [I feel sad all the time], 3 [I'm so sad, so unhappy that I cannot stand it]). Its reliability measured with Cronbach's alpha was 82 .

Substance use. The three items tool developed by the Ministry of Health and INEGI (2007) that measure alcohol consumption, marijuana and cocaine were used (e.g., In the last month have you used marijuana?). The answers were summed and then divided by the number of reagents to form the variable substance.

\subsection{Procedure}

Authorization from the authorities of the university was requested to conduct the study and subsequently voluntary and informed cooperation of students, who were guaranteed confidentiality of the information, was requested.

The administration of the scales was conducted in classrooms that meet the physical requirements needed for it to be answered: privacy, ventilation, lighting and furniture. For data analysis-with the SPSS statistical software (version 21), descriptive and inferential multivariate statistics were utilized; in particular, a discriminant analysis.

\section{Results}

\subsection{Discriminant Analysis for the Group of Women}

It is seen in the bivariate analysis with the Student's t-test for independent samples showed that women with high frequency of dating violence have major depression, substance use, hostile sexism, tensions in the couple's relationship and lower support experiences. The analysis of effect sizes suggests that the most important differences are presented in relational variables (see Table 1).

Table 1. Averages, standard deviation and t Student test for subgroups of women with high and low frequency dating violence

\begin{tabular}{lcccccc}
\hline & \multicolumn{6}{c}{ Women } \\
\cline { 2 - 7 } Variables & \multicolumn{7}{l}{ High $(n=173)$} & Low $(n=165)$ & & \\
\cline { 2 - 7 } & $M$ & $D S$ & $M$ & $D S$ & $t$ & Cohen's $d$ \\
\hline Hostile sexism & 1.88 & .91 & 1.69 & .84 & $3.96^{*}$ & .22 \\
Benevolent sexism & 3.52 & 1.14 & 3.30 & 1.21 & 2.92 & .19 \\
Substance use & .79 & .71 & .64 & .68 & $3.81^{*}$ & .16 \\
Depression & .43 & .32 & .34 & .29 & $6.50^{* *}$ & .29 \\
Tensions in the couple's relationship & .97 & .40 & .73 & .37 & $33.16^{* * *}$ & .62 \\
Support experiences & 2.57 & .31 & 2.72 & .23 & $-23.12^{* * *}$ & .55 \\
\hline
\end{tabular}

${ }^{*} p<.05 .{ }^{* *} p<.01 .{ }^{* * *} p<.001$. 
The discriminant function significantly differentiated groups of women with high and low dating violence $\left(X^{2}=\right.$ $42.28, p<.000$; Wilks' $1=.88$; canonical coefficient $=.34$ ). The integrated function by relational variables shows that tensions in the couple correlate positively with the discriminant function and support experiences do negatively (see Table 2).

Table 2. Correlation of the predictor variables with discriminant function

\begin{tabular}{lcc}
\hline \multicolumn{1}{c}{ Predictor variables } & $\begin{array}{c}\text { Correlation with Discriminant } \\
\text { Function }\end{array}$ & $\begin{array}{c}\text { Discriminant function's } \\
\text { standardized Coefficients }\end{array}$ \\
\hline Tensions in the couple's relationship & .86 & .72 \\
Support experiences & -.72 & -.53 \\
\hline
\end{tabular}

The variables included in the discriminant function properly classified $67.2 \%$ of young people in the groups of low and high level of violence in dating. These variables predict slightly better group membership with a low level of violence (see Table 3).

Table 3. Case classification based on the level of dating violence

\begin{tabular}{lccccc}
\hline & \multicolumn{4}{c}{ Predicted group they belong to } \\
\cline { 2 - 6 } Current group they belong to & $n$ & $n$ & $\%$ & $n$ & Low \\
\cline { 2 - 6 } Low & 173 & 110 & 63.6 & 63 & 36.6 \\
\hline High & 165 & 48 & 29.1 & 117 & 70.9 \\
\hline
\end{tabular}

Note. The total percentage of cases correctly classified $=67.2 \%$.

\subsection{Discriminant Analysis for the Group of Men}

The bivariate analysis performed, using Student's $t$ test for independent samples, shows that the group of men with high levels of dating violence reported greater gender stereotypes and substance use with respect to presenting low level of violence. From a relational point of view, the group of men with high violence reported higher stress and lower support experiences in their relationships. The most important differences were presented in substance use and tensions in the couple's relationship (see Table 4).

Table 4. Averages, standard deviation and $\mathrm{t}$ student for subgroups of men with high and low frequency dating violence

\begin{tabular}{lcccccc}
\hline & \multicolumn{7}{c}{ Men } \\
\cline { 2 - 7 } Variables & \multicolumn{7}{c}{ High $(n=210)$} & Low $(n=187)$ \\
\cline { 2 - 7 } & $M$ & $D S$ & $M$ & $D S$ & $t$ & Cohen's $d$ \\
\hline Hostile sexism & 2.53 & 1.07 & 2.18 & .98 & $11.01^{* * *}$ & .34 \\
Benevolent sexism & 3.41 & 1.04 & 3.15 & 1.08 & $6.29^{*}$ & .24 \\
Substance use & 1.21 & .85 & .85 & .81 & $18.18^{* * *}$ & .43 \\
Depression & .31 & .27 & .28 & .28 & .96 & .11 \\
Tensions in the couple's relationship & 1.01 & .41 & .77 & .43 & $30.84^{* * *}$ & .57 \\
Support experiences & 2.48 & .31 & 2.57 & .29 & $-13.83^{* * *}$ & .30 \\
\hline
\end{tabular}

${ }^{*} p<.05 .{ }^{* *} p<.01 .{ }^{* * *} p<.001$.

The discriminant function significantly differentiated groups of men with high and low dating violence $\left(X^{2}=\right.$ $53.87, p<.000 ;$ Wilks $^{\prime} \Lambda=.87$; canonical coefficient $=.36$. The function is composed of four variables, two of a 
personal nature (drug's use and hostile sexism) and two of a relational nature (tensions in the couple's relationship and experiences of support in the couple). Both personal variables relate positively with the discriminant function while in the case of relational variables, tensions in the couple's relationship did positively and support experiences negatively (see Table 5).

Table 5. Correlation of the predictor variables with discriminant function

\begin{tabular}{lcc}
\hline \multicolumn{1}{c}{ Predictor variables } & $\begin{array}{c}\text { Correlation with } \\
\text { Discriminant Function }\end{array}$ & $\begin{array}{c}\text { Discriminant function's } \\
\text { standardized Coefficients }\end{array}$ \\
\hline Substance use & .56 & .38 \\
Hostile sexism & .44 & .31 \\
Tensions in the couple's relationship & .73 & .63 \\
Support experiences & -.49 & -.40 \\
\hline
\end{tabular}

Integrated variables in the discriminant function properly classify $64 \%$ of cases and are more affective to identify men with high levels of violence in the couple since in this case classified adequately to $68.1 \%$ of them (see Table 6).

Table 6. Case classification based on the level of dating violence

\begin{tabular}{lccccc}
\hline & \multicolumn{4}{c}{ Predicted group they belong to } \\
\cline { 2 - 6 } Current group they belong to & $n$ & $n$ & $\%$ & $n$ & Low \\
\cline { 2 - 6 } Low & 210 & 143 & 68.1 & 67 & 31.9 \\
\hline High & 187 & 76 & 40.6 & 111 & 59.4 \\
\hline
\end{tabular}

Note. The total percentage of cases correctly classified $=64 \%$.

\section{Discussion}

From the results it can be inferred that relational variables, for both women and men, differentiate young people with low and high level of violence in their dating relationships. This finding is contrary to the results of studies conducted in Mexico, mostly with adolescent population where it is reported that aspects of the relationship are not associated with the presence of violence (King-Anacona, 2015). It is likely that these conflicting results are explained in part by the different stages of life where participants are located, it is expected in dating relationships in young people that generally are more stable, with more emotional involvement and intimacy than with adolescents (Morales \& Díaz, 2013), which are exposed to greater emotional demands and opportunities of tension or conflict (Rubio-Garay, Carrasco, Love, \& López-González, 2015).

Another interesting finding is that the experience of support, which is also a dyadic variable, acts as a protective factor for intimate partner violence (Castro \& Casique, 2010). Although there is little evidence of this in the literature there is evidence of empathy, a variable related to social support, it relates to minor dating violence (McCloskey \& Lichter, 2003; Rubio-Garay et al., 2015; Vagi, Rothman, Latzman, Teten, Hall, \& Breiding, 2013). This result suggests that affective ties play an important role in meeting couples (Acevedo, Restrepo, Giraldo, \& Tovar, 2007; Morales \& Díaz, 2013).

In the case of men it was found that in addition to the relational aspects are personal elements associated with dating violence. Young people with high violence reported greater substance use, which is consistent with other studies which show that there is a relationship between this variable and intimate partner violence (Guzmán et al., 2009; McNaughton et al., 2012; Rothman et al., 2012), which is explained by the fact that substance use is associated with a lower impulse control and less productive conflict management (Temple, Shorey, Fite, Stuart, $\&$ Le, 2013).

We also found that in the case of men's beliefs involving a hostile sexism (Cruz et al., 2005) there is an association with violence in their dating relationships. It seems that there are cultural gender stereotypes that 
hinder the relationships in these young people, perhaps because of the changes that exist in the attitudes and values of women to gender (Casique-Rodríguez, 2014; McCauley et al., 2013). This finding is relevant to the intervention programs regarding gender violence that contrary to what one would expect, involves more often women than men (Fernández de Juan, 2014).

We conclude that dating violence is a multifactorial problem to which are associated the personal aspects of life history and appropriation of culture by individuals as those relating to the interactions occurring in the couple (López et al., 2013). Significantly, the study shows the need to address the problem from a gender perspective as there are differences in the variables associated in dating violence in men and women.

It is suggested that future studies work on the robustness of the instruments in their psychometric properties. It is also necessary to conceptually refine the variable support experience, exploring the development of expressions of support, affection and commitment to young couples. It is also needed to inquire about dating violence regarding the type of relationship and expectations of each member regarding closeness, loyalty, intimacy, control and commitment as these differences can create tensions and conflicts in couples (Draucker et al., 2012).

As for the intervention it intends to implement actions aimed at preventing substance use and modify gender stereotypes, in particular those relating to the supremacy of man; also the development of actions to teach young people to manage tensions in their couple's relationship, and to develop the necessary empathy toward their couple to provide effective support (Méndez \& García, 2015; Rubio-Garay et al., 2015).

\section{References}

Acevedo, V., Restrepo, L., \& Tovar, J. (2007). Parejas satisfechas de larga duración en la ciudad de Cali [Fulfilled long-term couples in the city of Cali]. Pensamiento Psicológico, 3, 85-107.

Casique-Rodríguez, I. (2014). Empoderamiento de las jóvenes Mexicanas y prevención de la violencia en el noviazgo [Empowerment of young Mexican women and dating violence prevention]. Papeles de Población, 20(18), 27-56. Retrieved from http://www.redalyc.org/articulo.oa?id=11232827003

Castro, R., \& Casique, I. (2010). Violencia en el noviazgo entre los jóvenes mexicanos [Dating violence among young Mexicans]. Cuernavaca: UNAM.

Clarey, A., Hokoda, A., \& Ulloa, C. (2010). Anger control and acceptance of violence as mediators in the relationship between exposure to interparental conflict and dating violence perpetration in Mexican adolescents. Journal of Family Violence, 25(7), 619-625. http://dx.doi.org/10.1007/s10896-010-9315-7

Cruz, C. E., Zempoalteclat, V., \& Correa, F. E. (2005). Perfiles de sexismo en la ciudad de México: Validación del cuestionario de medición del sexismo ambivalente [Sexism profiles in Mexico City: Validation of measurement questionnaire ambivalent sexism]. Enseñanza e Investigación en Psicología, 10, 381-395. Retrieved from http://www.redalyc.org/articulo.oa?id=29210212

Draucker, C. B., Martsolf, D., \& Stephenson, P. (2012). Ambiguity and violence in adolescent dating relationships. Journal of Child and Adolescent Psychiatric Nursing, 25, 149-157. http://dx.doi.org/10.1111/j.1744-6171.2012.00338.x

Ellis, W. E., Chung-Hall, J., \& Dumas, T. M. (2013). The role of peer group aggression in predicting adolescent dating violence and relationship quality. Journal of Youth and Adolescence, 42, 487-499. http://dx.doi.org/10.1007/s10964-012-9797-0

Fernández de Juan, T. (2014). La educación sexual y de género vs. el maltrato en la pareja. Escenario sobre la violencia en jóvenes de Baja California [Sex and gender education vs. abuse in the couple. Stage on youth violence in Baja California]. Estudios Fronterizos, 15(30), 73-96.

Foshee, V. (1996). Gender differences in adolescent dating abuse prevalence, types, and injuries. Health Education Research, 11, 275-286. http://dx.doi.org/10.1093/her/11.3.275-a

Fritz, P., Slep, A., \& O'Leary, K. (2012). Couple-level analysis of the relation between family-of-origin aggression and intimate partner violence. Psychology of Violence, 2, 139-153. http://dx.doi.org/10.1037/a0027370

González-Ortega, I., Echeburúa, E., \& de Corral, P. (2008). Variables significativas en las relaciones violentas en parejas jóvenes: Una revisión [Significant variables in violent relationships in young couples: A review. Behavioral Psychology]. Behavioral Psychology, 16(2), 207-225. 
Gover, A. R., Jennings, W. G., \& Tewksbury, R. (2009). Adolescent male and female gang members'experience with violent victimization, dating violence, and sexual assault. American Journal of Criminal Justice, 34, 103-115. http://dx.doi.org/10.1007/s12103-008-9053-z

Guzmán, F. R., Esparza, S. E., Alcántara, S. A., Escobedo, I. Y., \& Henggeler, T. (2009). Consumo de alcohol en jóvenes y su relación con la violencia psicológica en el noviazgo [Alcohol consumption in young people and it relationship with psychological violence in dating]. Revista Electrónica Salud Mental, Alcohol y Drogas, 5, 1-14. Retrieved from http://www.redalyc.org/articulo.oa?id=80313060003

Instituto Nacional de Estadística y Geografía. (2007). Encuesta Nacional de Violencia en las Relaciones de Noviazgo [National Survey of Violence in dating relationships]. México: INEGI e IMJUVE.

Instituto Nacional de Estadística y Geografía. (2011). Encuesta Nacional sobre la Dinámica de las Relaciones en los Hogares [National Survey on the Dynamics of Household Relationships]. México: INEGI.

Jurado, S., Villegas, M. E., Méndez, L., Rodríguez, F., Loperena, V., \& Varela, R. (1998). La estandarización del Inventario de Depresión de Beck para los residentes de la Ciudad de México [The standardization of the Beck Depression Inventory for residents of Mexico City]. Salud Mental, 21, 26-31.

López, F., Moral, J., Díaz-Loving, R., \& Cienfuegos, Y. (2013). Violencia en la pareja. Un análisis desde una perspectiva ecológica [Intimate partner violence. An analysis from an ecological perspective]. Ciencia Ergo Sum, 20, 6-16. Retrieved from http://www.redalyc.org/articulo.oa?id=10425466009

McCloskey, L. A., \& Lichter, E. L. (2003). The contribution of marital violence to adolescent aggression across different relationships. Journal of Interpersonal Violence, 18, 390-412. http://dx.doi.org/10.1177/0886260503251179

McCauley, H. L., Tancredi, D. J., Silverman, J. G., Decker, M. R., Austin, S. B., \& McCormick, M. (2013). Gender-Equitable Attitudes, Bystander Behavior, and Recent Abuse Perpetration Against Heterosexual Dating Partners of Male High School Athletes. American Journal of Public Health, 103, 1882-1887. http://dx.doi.org/10.2105/AJPH.2013.301443

McNaughton, H. L., Foshee, V., Bauer, D., \& Ennett, S. (2012). Heavy Alcohol Use and Dating Violence Perpetration During Adolescence: Family, Peer and Neighborhood Violence as Moderators. Prevention Science, 13, 340-349. http://dx.doi.org/0.1007/ s11121-011-0215-8

Méndez, M. D. P., \& García, M. (2015). Relación entre las estrategias de manejo del conflicto y la percepción de la violencia situacional en la pareja [Relationship between strategies of conflict management and perception of situational couple violence]. Revista Colombiana de Psicología, 24, 99-111. http://dx.doi.org/10.15446/rcp.v24n1.41439

Morales, R. M., \& Díaz, D. (2013). Noviazgo: Evolución del significado psicológico durante la adolescencia [Courtship: Evolution of psychological significance during adolescence]. Uaricha, 10, 20-31. Retrieved from http://www.revistauaricha.umich.mx/Articulos/uaricha_1022_020-031.pdf

Olvera, J. A., Arias, J., \& Amador, R. (2012). Tipos de violencia en el noviazgo: Estudiantes universitarias de la UAEM, Zumpango [Types of violence in the courtship: In university students UAEM Zumpango]. Revista Electrónica de Psicología Iztacala, 15(1), 150-171. Retrived from http://www.revistas.unam.mx/index.php/repi/article/view/30908/28641

Pepler, D. (2012). The development of dating violence: What doesn't develop, what does develop, how does it develop, and what can we do about it? Prevention Science, 13, 402-409. http://dx.doi.org/10.1007/s11121-012-0308-z

Ramírez-Rivera, C. A., \& Núñez Luna, D. A. (2010). Violencia en la relación de noviazgo en jóvenes universitarios: Un estudio exploratorio [Violence in dating relationship in university students: An exploratory study]. Enseñanza e Investigación en Psicología, 15, 273-283.

Recio, P., Cuadrado, I., \& Ramos, E. (2007). Propiedades psicométricas de la Escala de Detección de Sexismo en Adolescentes [Psychometric properties of the scale Adolescent Sexism Detection]. Psicothema, 19(3), 522-528.

Rey-Anacona, C. A. (2015). Variables asociadas a los malos tratos en el noviazgo en adolescentes y adultos jóvenes. Acta Colombiana de Psicología, 18, 159-171. http://dx.doi.org/10.14718/ACP.2015.18.1.15

Rivera-Rivera, L., Allen, B., Rodríguez-Ortega, G., Chávez-Ayala, R., \& Lazcano-Ponce, E. (2006). Violencia durante el noviazgo, depresión y conductas de riesgo en estudiantes femeninas (12-24 años) [Dating 
violence, depression and risk behaviors in female students (12-24 years)]. Salud Pública México, 48(2), 288-296. http://dx.doi.org/10.1590/S0036-36342006000800009

Rojas-Solís, J. L., \& Carpintero, R. E. (2011). Sexismo y agresiones físicas, sexuales y verbales-emocionales, en relaciones de noviazgo de estudiantes universitarios [Sexism and physical, sexual and verbal-emotional aggression in dating relationships of college students]. Electronic Journal of Research in Educational Psychology, 9, 541-564. Retreived from http://www.redalyc.org/articulo.oa?id=293122840004

Rojas-Solís, J. L. (2011). Transformaciones socioculturales y aspectos de género: Algunas implicaciones para el estudio de violencia en pareja [Sociocultural transformations and gender issues: Some implications for the study of violence as a couple]. Revista Electrónica de Psicología Iztacala, 14, 252-272. Retreived from http://www.medigraphic.com/pdfs /epsicologia/epi-2011/epi113n.pdf

Rothman, E. F., McNaughton, R. L., Johnson, R. M., \& LaValley, M. (2012). Does the alcohol make them do it? Dating violence perpetration and drinking among youth. Epidemiologic Review, 34, 103-119. http://dx.doi.org/10.1093/epirev/mxr027

Rubio-Garay, F., Carrasco, M. A., Amor, P. J., \& López-González, M. A. (2015). Factores asociados a la violencia en el noviazgo entre adolescentes: Una revisión crítica [Factors associated with dating violenceamong adolescents: A critical review]. Anuario de Psicología Jurídica, 25, 47-53. http://dx.doi.org/10.1016/j.apj.2015.01.001

Saldivia, C., \& Vizcarra, B. (2012). Consumo de Drogas y Violencia en el Noviazgo en Estudiantes Universitarios del Sur de Chile [Use of drugs and Dating Violence in Southern Chile University Students]. Terapia Psicológica, 30(2), 43-49. http://dx.doi.org/10.4067/S0718-48082012000200004

Secretaría de Salud. (2011). Encuesta Nacional de Adicciones [National Survey of Addictions]. México: Secretaría de Salud e Instituto Nacional de Psiquiatría.

Silverman, J. G., Raj, A., Mucci, L. A., \& Hathaway, J. E. (2001). Dating violence against adolescent girls and associated substance use, unhealthy weight control, sexual risk behavior, pregnancy, and suicidality. Journal of the American Medical Association, 286, 572-579. http://dx.doi.org/10.1001/jama.286.5.572

Temple, J., Shorey, R., Fite, P., Stuart, G. L., \& Donna, V. (2013). Substance use as a longitudinal predictor of the perpetration of teen dating violence. Journal of Youth and Adolescence, 42, 596-606. http://dx.doi.org/10.1007/s10964-012-9877-1

Tharp, A. (2012). Dating matters: The next generation of teen dating violence prevention. Prevention Science, 13 , 398-401. http://dx.doi.org/10.1007/s11121-012-0307-0

Vagi, K., Rothman, E., Latzman, N., Teten, A., Hall, D., \& Breiding, M. (2013). Beyond correlates: A review of risk and protective factors for adolescent dating violence perpetration. Journal of Youth and Adolescence, 42, 633-649. http://dx.doi.org/10.1007/s10964-013-9907-7

Vargas, M. (2012). Amores chidos: Guía para docentes: Sensibilización, prevención y atención básica de la violencia en el noviazgo con las y los jóvenes [Groovy love: A guide for teachers: Awareness, prevention and basic care of dating violence with the young people]. México, D. F.: Comisión Nacional para Prevenir y Erradicar la Violencia contra las Mujeres.

Vázquez, G. V., \& Castro, R. (2008). Mi novio sería capaz de matarme? Violencia en el noviazgo entre adolescentes de la Universidad Autónoma Chapingo, México [My boyfriend would be capable of kill me? Dating violence among adolescents of Chapingo, Mexico]. Revista Latinoamericana de Ciencias Sociales, Niñez y Juventud, 6(2), 709-738.

Vázquez, F., Torres, A., Otero, P., Blanco, V., \& López, M. (2010). Prevalencia y factores de riesgo de la violencia contra la mujer en estudiantes universitarias españolas [Prevalence and risk factors of violence against women in Spanish university students]. Psicothema, 22(2), 196-201.

Vizcarra, M. B., \& Poo, A. M. (2010). Violencia de pareja en estudiantes universitarios del sur de Chile [Intimate partner violence among university students in southern Chile]. Universitas Psychologica, 10(10), 89-98.

Wekerle, C., \& Wolfe, D. A. (1999). Dating violence in mid-adolescence: Theory, significance, and emerging prevention initiatives. Clinical Psychological Review, 19, 435-456. http://dx.doi.org/10.1016/S0272-7358 


\section{Copyrights}

Copyright for this article is retained by the author(s), with first publication rights granted to the journal.

This is an open-access article distributed under the terms and conditions of the Creative Commons Attribution license (http://creativecommons.org/licenses/by/3.0/). 